\title{
Teaching Technical Teacher Candidates with Various Types of Learning Styles: Online and Face-to-Face Compounds
}

\author{
Hamonangan Tambunan ${ }^{1}$, Marsangkap Silitonga ${ }^{2} \&$ Uli Basa Sidabutar ${ }^{3}$ \\ ${ }^{1}$ Educational Technology, Postgraduate Program, State University of Medan, Indonesia \\ ${ }^{2}$ Electrical Engineering Education, State University of Medan, Indonesia \\ ${ }^{3}$ Information \& Communication Technology Education, State University of Medan, Indonesia \\ Correspondence: Hamonangan Tambunan, Educational Technology, Postgraduate Program, State University of \\ Medan, Indonesia. E-mail: hamonangantambunan@unimed.ac.id
}

Received: August 7, 2019

Accepted: August 25, 2019

Online Published: September 3, 2019

doi:10.5430/ijhe.v8n5p233

URL: https://doi.org/10.5430/ijhe.v8n5p233

\begin{abstract}
Differences in statements about the practice of blended learning (a combination of online and face-to-face instruction) were found in experiments conducted on prospective students of engineering teachers. There were various forms of learning, and - significantly - the various types of learning styles had a significant influence on competence. Group members' competencies based on learning is significantly different, but based on the type of learning style, there are competencies which are not significantly different between several groups
\end{abstract}

Keywords: competence, blended learning, learning style

\section{Introduction}

Blended learning - through the practice of combining online and face-to-face learning-attracts the attention of education and teaching researchers; and some of them claim it has advantages (Dendir, 2018; Nemetz, Eager, \& Limpaphayom, 2017). One covers the other's weaknesses through the advantages possessed during the learning process (Bolsen, Evans, \& Fleming, 2016; Morgan, 2015; Courtney \& Kelly, 2015). So, a pedagogical, student-centered, and collaborative approach is implemented - one which is appropriate teaching to form quality teachers (Kennedy, 2016; Pekkarinen \& Hirsto, 2017; Cutri \& Whiting, 2018). Many emphasize that the high quality of the teacher is necessary to produce quality learning (McIlveen, 2018; Parsons, Ankrum, \& Morewood, 2016; Mohamed, Valcke, \& De Wever, 2016; Wong et al., 2018; Ahonen et al., 2014; Zerihun, Beishuizen, \& Van Os, 2011; Wang \& Gao, 2016; DeCoito, 2006).

Some claim that there is a variety of learning which is done through blended learning-including inquiry-based, problem-based, project-based learning; and those that relate to authentic professional practices, phenomena, problems, and situations (Ge, Planas, \& Huang, 2015; Hunt, 2015). Such a method can accommodate students now and in the future, because of its being supported by digital and mobile communication in the practice of making content interactive and lessons adapted to the cultural preferences of students (Ruhalahti, Korhonen, \& Rasi, 2017; Satar \& Akcan, 2014). Moreover, some have acknowledged that it has a positive impact on students and learning outcomes because it is useful for transferring knowledge, and because of work while learning can also take place (Hortovanyi \& Ferincz, 2015, Chandra \& Briskey, 2012). In that condition, Information and Communication Technology (ICT) plays a crucial role when the teaching and learning process is being implemented (Çardak \& Selvi, 2016; Zuber, 2016; Ruhalahti, Aarnio, \& Ruokamo, 2018; Khusainova \& Lukoyanova, 2018) so that learning becomes more dynamic, interactive, and motivated (Boelens, Voet, \& De Wever, 2018; Chmiel, Shaha, \& Schneider, 2017; Bower, Kenney, Dalgarno, Lee, \& Kennedy, 2014; Broadbent, 2017; Cuesta Medina, 2017; Afacan, 2015; Hughes, 2007). Independence of learning and a rich understanding of students can also be created (Nickels \& Gartner; 2018).

Blended learning has been tried out on teacher training and is said to be able to provide opportunities for participants to have experienced social and cognitive presence. Participants also experience convenience because they feel helped through discussions with colleagues and facilitators, whether synchronously or asynchronously (Ndlovu \& Mostert; 2017; Bicen, Ozdamli, \& Uzunboylu, 2012; Donnelly, 2006). However, some researchers state that —although not entirely — learning outcomes through blended learning significantly differ from traditional learning (Botts, Carter, \& 
Crockett, 2018). However, the researchers did not explicitly show the pattern of integration between online and face-to-face interactions used. In that case, it has been stated that integration has an impact on academic achievement (Kim McShane, 2004). Likewise, with students' individual differences and learning characteristics—one of which is learning style - there is also an influence (Green \& Sammons, 2014; Chang-Tik; 2017). Different individuals in different conditions are said to tend to give different results (Yang \& Quadir; 2018; Shen \&Palmeri; 2016; She, 2005; Premlatha, Dharani, \& Geetha, 2014). However, there are various statements that differ from each other. On the one hand, there are those who claim it has no effect (Kirschner, 2017; Brunton, 2014). On the other hand, those do not fully agree; and some even explicitly state that learning styles are crucial (Huang, 2018; Toyama \& Yamazaki, 2019; Martinez \& Tuesca, 2019).

Until now, there has not been enough information that explains the impact that various online and face-to-face combinations of blended learning have on the competency of teacher candidates, who have various types of learning styles. It is important because some people say the success of blended learning is not solely based on the integration of classroom teaching with digital media in simple ways; instead, learning patterns and practices can also change (López-Pérez, Pérez-López, \& Rodríguez-Ariza, 2011; George-Walker \& Keeffe (2010). The competence of teacher candidates is necessary because it is a necessary provision for ' when they are involved in later teaching assignments (Kömür, 2010; Baran, Correia, \& Thompson, 2011; Zhu, Wang, Cai, Engels, 2013). It is essential that prospective teachers in electrical engineering be skilled in mastering theory and practice related to engineering sciences, engineering analysis and investigation, engineering design, and engineering practice (Keltikangas \& Martinsuo, 2009). It is needed for planning, implementing, and evaluating learning (Goodwin \& Kosnik, 2013; Kantonidou \& Chatzarakis, 2005).

In general, prospective electrical engineering teachers have diverse backgrounds, including learning styles. The combination of online and face-to-face on blended learning is also possible in various forms. Then, it is possible to require diverse forms of learning as well, in order to obtain maximum learning results. Therefore it is possible to form online and face-to-face compositions suitable for certain types of learning styles to give better results. Then the most appropriate form of learning for certain types of learning styles are tested through an experiment by questioning three things, namely:

- Does the diversity of blended learning have an impact on teacher candidates' competence?

- Does the diversity of types of learning styles impact on teacher candidates' competency?

- What is the best form of blended learning for teaching teacher candidates based on their learning style types?

\section{Literature Review}

\subsection{Teacher Candidates' Competence in Blended Learning}

Some sources emphasize that the incorporation of online and face-to-face learning provides immense opportunities for students to interact well with fellow students as well as with lecturers, whether online or offline (Lim, Yan, \& Xiong, 2015; Ra, Chin, \& Lim, 2016). In this way, students can quickly get learning assistance in the form of guidance or demonstration/simulation, whether directly or indirectly. Some people have acknowledged the form of convergence between technology-based environments and traditional settings as being right; and it has been implemented in virtual laboratories (Vitale \& Linn, 2018; De Jong, Linn, \& Zacharia, 2013) and also in flipped classrooms (Chapman \& Hassein, 2018; Gilboy, Heinerichs, \& Pazzaglia, 2015). Independent learning and collaboration can be created (Stoltzfus, 2016; Lim \& Wang, 2015) because it is supported through more communication channels (Kimmelmann \& Lang, 2018).

Because the speed of students to process information is varied (Alexakis \& Andert, 2015; Kurtz et al., 2013) it is essential to choose learning that is suitable for each group. A variety of online and face-to-face mixtures in blended learning may be formed to meet those needs so that the provision of learning assistance can be more efficient in each group based on the type of individual learning characteristics shared (Haruehansawasin \& Kiattikomol, 2017). Online learning can be a place to provide opportunities for prospective teacher students who are fast learners and who have a high degree of learning creativity; while slow learners are assisted through face-to-face learning so that this can provide encouraging results (Dunn, Giannitti, Murray, Rossi, Geisert, \& Quinn, 1990; Phillips, Stott, \& Birrell, 1987; William, 1999; Ansari Ricci, Persiani, Williams, \& Ribas, 2019; Wetzel, De Arment, \& Reed, 2015). The portion of lecturer involvement in the classroom, and study time for students independently, can be arranged as needed. 
Teaching materials - to shape the professional competence of prospective teachers - are good if delivered through blended learning, because the combination of online and face-to-face instruction has advantages (Jean in Inoue, 2010). The competency of prospective electrical engineering teachers is to cover the concepts of electricity and skills related to selecting the appropriate tool; dexterity using tools on the task; the level of precision of the work results; efficient use of time in carrying out tasks; and work safety.

The combination of online and face-to-face instruction can be in various forms. This study uses three types of variations: namely, (1) $25 \%$ online and $75 \%$ face-to-face instruction; (2) $50 \%$ online and $50 \%$ face-to-face instruction; and (3) $75 \%$ online and $25 \%$ face-to-face instruction. This variety of combinations based on the idea that individuals differ in their speed of digesting information. Face-to-face instruction is an opportunity to facilitate and motivate slow students; and online instruction provides broad opportunities for students to learn independently, especially those who have high learning creativity (Zwart, Van Luit, Noroozi, \& Goei, 2017; Mirabella et al., 2004; Wilke, King, Ashmore, \& Stanley, 2016; Kissau, 2014). Thus, their competences can be built together maximally because it is possible for these differences to be accommodated (Kuo, Belland, Schroder, \& Walker, 2014). This is known through measurement and assessment (Moss \& Brookhart, 2009).

\subsection{Learning Style in Blended Learning}

Learning experiences theory (Kolb, 1984) explains that learning style is a process whereby knowledge is formed through the transformation of experience. It is a set of holistic processes (in a continuous cycle) which start from the stages of Concrete Experience (CE), Reflective Observation (RO), and Active Experimentation (AE) up to Abstract Conceptualization (AC). In blended learning practices, prepared teaching materials refer to the process/form of delivering; so that students with various types of learning styles can be served. Kolb illustrates that CE and AC are bipolar on a continuum and are orthogonal to a second bipolar continuum of RO and AE. Two adjacent mode preferences of the experiential learning cycle lead to a combination of four basic learning styles known as the Diverger (between $\mathrm{CE}$ and RO), the Assimilator (between RO and AC), the Converger (between $\mathrm{AC}$ and $\mathrm{AE}$ ), and the Accommodator (between $\mathrm{AE}$ and $\mathrm{CE}$ ). Someone may have one of the four learning styles but can and should learn to use the other modes. Divergers have strong imaginative abilities; are smart to use different points of view to see things; are creative, and can work with others. Assimilators can make theoretical models; and prefer inductive reasoning and abstract ideas. Convergers have a strong practical orientation; are generally deductive, and tend not to be emotional. Accommodators like doing things and solving problems intuitively, taking risks in the here-and-now (Manolis, Burns, Assudani, \& Chinta, 2013).

It has been suggested that teachers use a variety of approaches to be able to accommodate diverse modes of student learning. Some people say that traditional students generally prefer to start from the RO-AC quadrant, whereas non-traditional students will prefer the AC-AE quadrant (Svinicki \& Dixon, 1987; Vince, 1998; Wynd \& Bozman, 1996). It illustrates that using more face-to-face instruction than online instruction in blended learning is probably more suitable for diverger types. Instead, more online portions are probably more suitable for converger types. The selection of the right form of learning can provide maximum results - namely, high student performance in the course (Chimmalgi, 2018; Vizeshfar \& Torabizadeh, 2018; Brunton, 2014). In other words, the blended learning combination of online and face-to-face instruction, which is suitable for the type of learning style of the teacher candidates, can form maximally professional competence.

\section{Method}

\subsection{Tools and Materials}

We built learning webs (URL: http://jpte-ft-unimed.edu20.org) as a container in this study. Two experts (IT and learning technology) were involved in validating the display aspects, completeness of navigation, information loading space, and ease of use of the site. Some inputs from them were accommodated in order for it to become feasible to use.

Teaching materials related to the analysis of the electric power system are prepared and developed, referring to the curriculum used in the Department of Electrical Engineering Education. There are three experienced lecturers involved in order to assess the conformity aspects of the material content scope with learning objectives, language clarity, material description structure, image clarity related to the material, video display, and practice management. Several parts are corrected based on their input so that it is feasible to implement the teaching materials.

Competency test instruments include mastery theory tests and skills assessment sheets, which are developed based on learning objectives. There are 25 questions in the form of essays - namely to measure mastery of the theory. The practical skills assessment sheet includes five aspects-namely, choosing the right tool; dexterity using tools on the 
task; the level of precision of the work results; efficient use of time in carrying out tasks; and work safety. The score of theory mastery determined by giving a score of 2 if true and 0 if wrong for all items so that the maximum total score of mastery of the theory becomes 50 . Assessment of skill is a score range of $0-10$ for each aspect, so the maximum total score of skills assessment becomes 50. Then, the competency score is the combination of two scores - those of the 35 participants and the three raters involved (namely, the lecturer in electrical engineering). After testing, there appeared to be no significant differences between them $(\mathrm{F}=.145, \mathrm{Sig},=.865)$ and concluded it was feasible to use. For tracking participants' learning style types, Kolb Learning Style Inventory 4.0 was used.

\subsection{Participants and Design}

A total of 84 participants assessed through the Kolb Learning Style Inventory 4.0 were drawn from students participating in the Power System Analysis course at the Department of Electrical Engineering Education at the State University of Medan, Indonesia. They consist of four groups of 21 people each. Each group is comprised of one of four learning style types: Diverger (Di), Assimilator (As), Converger (Co), and Accommodation (Ac). A total of 7 participants were drawn randomly from each learning style group, and they were determined to be members of learning groups consisting of 25-75 blended (BL1), 50-50 blended (BL2), and 75-25 blended (BL3). The experimental group is a 3 x 4 design, which consists of Group 1 (BL1Di), Group 2 (BL1As), Group 3 (BL1Co), Group 4 (BL1Ac), Group 5 (BL2Di), Group 6 (BL2As), Group 7 (BL2Co), Group 8 (BL2 Ac), Group 9 (BL3Di), Group 10 (BL3As), Group 11 (BL3Co), and Group 12 (BL3Ac).

\subsection{Procedure}

All groups were given a pretest before being involved in the experiment, and they had the same initial competencies $(F=2.149$, Sig. $=0.76>.05)$. Furthermore, the learning activities were carried out by one lecturer in each group, with the number of activities being 12 times during one semester. When learning online participants get access codes for each learning group are made different. The combination of learning from each group is BL1 (4 times online and 8 times face to face); BL2 (6 times online and 6 times face to face); and BL3 (8 times online and 4 times face to face) at the time of implementation with the same material. As soon as the learning ends, the competency test is carried out and the competency data of each group member is recorded.

\subsection{Data Analysis}

The competency data is described through descriptive statistics. The requirements for normality and homogeneity were tested respectively through the Kolmogorov Smirnov Test and Levene Test. The impact of the different forms of learning, the variety of types of learning styles, and the interaction of learning with learning styles towards competencies were tested through two-way ANOVA at the significance level of .05.

Furthermore, the Post Hoc Test was used to see differences in the average of competencies between learning groups and the type of learning style group. The most suitable combination is determined based on the plot of the competencies of each group type of learning style in each form of learning. All data analysis is carried out through IBM's SPSS 25 program.

\section{Results}

\subsection{Competence Description}

The competency description of participants in each learning group with 28 members (Table 1) shows that BL1 group (Blended 25-75) has the highest score on average, followed by the other groups: BL2 group (50-50 Blended) and BL3 (Blended 75-25).

Table 1. Competence description, based on blended type

\begin{tabular}{ccc}
\hline Learning Groups & Mean, $n=28$ & Std. Deviation \\
\hline BL1 (25-75 Blended) & 73.68 & 7.977 \\
BL2 (50-50 Blended) & 75.61 & 6.437 \\
BL3 (75-25 Blended) & 71.04 & 6.818 \\
\hline
\end{tabular}

Based on 21-member learning-style-type group scores, Table 2 shows that the As (Assimilator)-type group members have the highest scores (on average) than do members of the other groups. The next highest are Di (Diverger), Ac (Accommodator), and Converger (Co) (Table 2). 
Table 2. Competence description, based on learning style type groups

\begin{tabular}{ccc}
\hline Learning Style Groups & Mean, $n=21$ & Std. Deviation \\
\hline Di (Diverger) & 74.76 & 9.006 \\
As (Assimilator) & 76.33 & 7.492 \\
Co (Converger) & 70.48 & 7.336 \\
Ac (Accomodator) & 72.19 & 2.294 \\
\hline
\end{tabular}

Participants' competency scores - based on learning style type, based on learning group (Table 3), indicate that learning style type (Di) Diverger has the highest average score in the BL1 learning group (25-75 blended), followed by the BL2 group (50-50 blended) and BL3 group ( $75-25$ blended). The average score of the As (Assimilator) group sorted from the highest score in the BL2 group (50-50 blended), followed by the BL1 group (25-75 blended), and the BL3 group (75-25 blended). Co (Converger) learning style types have the highest competency score in the BL3 group (75-25 blended), followed by the BL2 group (50-50 blended) and the BL1 group (75-25 blended). Meanwhile, the Accommodation type has the highest competency score in the BL3 group (75-25 blended), followed by the BL2 group (50-50 blended) and the BL1 group (25-75 blended).

Table 3. Competence description based on learning style in blended learning type groups

\begin{tabular}{cccc}
\hline Learning Style Groups & Blended Learning Groups & Mean, $n=7$ & Std. Deviation \\
\hline Di (Diverger) & BL1 (25-75 Blended) & 83.29 & 2.690 \\
& BL2 (50-50 Blended) & 77.86 & 2.911 \\
& BL3 (75-25 Blended) & 63.14 & 2.193 \\
As (Assimilator) & BL1 (25-75 Blended) & 76.86 & 4.670 \\
& BL2 (50-50 Blended) & 84.00 & 2.309 \\
& BL3 (75-25 Blended) & 68.14 & 3.579 \\
Co (Converger) & BL1 (25-75 Blended) & 63.71 & 3.147 \\
& BL2 (50-50 Blended) & 68.43 & 2.820 \\
& BL3 (75-25 Blended) & 79.29 & 3.773 \\
Ac (Accomodator) & BL1 (25-75 Blended) & 70.86 & 1.676 \\
& BL2 (50-50 Blended) & 72.14 & 1.574 \\
& BL3 (75-25 Blended) & 72.57 & 2.070
\end{tabular}

The average competency score of the participants obtained in the learning group by learning style type (Table 4) shows that the Diverger type had the highest and numerical average scores in the BL1 learning group (25-75 blended) followed by the Assimilator, Accommodator, and Converger types. Participants' competency scores in the BL2 learning group (50-50 blended), sorted from the highest to lowest scores, are Assimilator, Diverger, Accommodation, and Converger types. In the BL3 learning group (75-25 blended), the converger type scored the highest, followed by the Accommodator, Assimilator, and Diverger types. 
Table 4. Competence description based on learning style in blended learning groups

\begin{tabular}{cccc}
\hline Blended Learning Groups & Learning Style Groups & Mean, $n=7$ & Std. Deviation \\
\hline 25-75 Blended & Diverger & 83.29 & 2.690 \\
& Assimilator & 76.86 & 4.670 \\
& Converger & 63.71 & 3.147 \\
& Accomodator & 70.86 & 1.676 \\
\hline 50-50 Blended & Diverger & 77.86 & 2.911 \\
& Assimilator & 84.00 & 2.309 \\
& Converger & 68.43 & 2.820 \\
& Accomodator & 72.14 & 1.574 \\
\hline 75-25 Blended & Diverger & 63.14 & 2.193 \\
& Assimilator & 68.14 & 3.579 \\
& Converger & 79.29 & 3.773 \\
& Accomodator & 73.57 & 2.820
\end{tabular}

Data normality was fulfilled based on Kolmogorov-Smirnov Test $(\mathrm{N}=84$, Mean=71.79, Std. Deviation=6.174, Test statistic=.089), and (Asymp.Sig (2-tailed)=.113>. 05). The same was right with data homogeneity based on the Mean, Median, Median, and with adjusted df; and the Trimmed Mean is Sig.> .05 (Table 5).

Table 5. Levene's test of competence equality of error variances

\begin{tabular}{cccccc}
\hline & Levene Statistic & DF1 & DF2 & Sig. \\
\hline Competence & Based on Mean & 1.477 & 11 & 72 & .159 \\
& Based on Median & .970 & 11 & 72 & .481 \\
& $\begin{array}{c}\text { Based on Median and } \\
\text { with adjusted df } \\
\text { Based on Trimmed } \\
\text { mean }\end{array}$ & .970 & 11 & 46.798 & .486 \\
& 1.433 & 11 & 72 & .177 \\
\hline
\end{tabular}

\subsection{Blended Learning's and Learning Styles' Influence}

ANOVA test results (Table 6) indicate the various forms of Blended learning, the variety of learning styles, and their interactions influence the competence of the prospective teacher significantly (Intercept, F=51381.495, DF $=11$, Sig. $=.000<.05)$. Then Blended learning-BL varieties have a significant influence on competence $(\mathrm{F}=16,725, \mathrm{df}=2$, Sig. $=.00<.05)$ as well as the LS-style Learning variety $(\mathrm{F}=16,246, \mathrm{df}=3, \mathrm{Sig} .=.00<.05)$. Also their interaction (BL * LS $)$ is significant $(\mathrm{F}=57,219$, Sig. $=00<.05)$.

Table 6. Blended learning's and learning style's effects

\begin{tabular}{cccccc}
\hline Source & $\begin{array}{c}\text { Type III Sum } \\
\text { of Squares }\end{array}$ & DF & Mean Square & $F$ & Sig. \\
\hline Corrected Model & $3751.845^{\mathrm{a}}$ & 11 & 341.077 & 38.682 & .000 \\
Intercept & 453054.298 & 1 & 453054.298 & 51381.495 & .000 \\
BL (Blended Learning) & 294.952 & 2 & 147.476 & 16.725 & .000 \\
LS (Learning Style) & 429.750 & 3 & 143.250 & 16.246 & .000 \\
BL * LS & 3027.143 & 6 & 504.524 & 57.219 & .000 \\
Error & 634.857 & 72 & 8.817 & & \\
Total & 457441.000 & 84 & & & \\
Corrected Total & 4386.702 & 83 & & & \\
\hline
\end{tabular}


Post Hoc Test results (Table 7) show the significant differences among blended learning groups (Sig. <.05) and among groups of learning style types (Table 8). The data show that several pairs of groups are not significant—namely, Diverger-Assimilator (Sig.=.324> .05), Converger-Accommodator (Sig. =. 250> .05), while other pairs are significant (Sig. <.05).

Table 7. Competence comparison among blended learning groups

\begin{tabular}{|c|c|c|c|c|c|c|}
\hline \multirow[b]{2}{*}{ (I) Blended } & \multirow[b]{2}{*}{ (J) Blended } & \multirow[b]{2}{*}{$\begin{array}{c}\text { Mean Difference } \\
(I-J)\end{array}$} & \multirow[b]{2}{*}{ Std. Error } & \multirow[b]{2}{*}{ Sig. } & \multicolumn{2}{|c|}{$\begin{array}{l}\text { 95\% Confidence } \\
\text { Interval }\end{array}$} \\
\hline & & & & & $\begin{array}{l}\text { Lower } \\
\text { Bound }\end{array}$ & $\begin{array}{l}\text { Upper } \\
\text { Bound }\end{array}$ \\
\hline $25-75$ & 50-50 Blended & $-1.93^{*}$ & .794 & .046 & -3.83 & -.03 \\
\hline Blended & 75-25 Blended & $2.64^{*}$ & .794 & .004 & .74 & 4.54 \\
\hline $50-50$ & 25-75 Blended & $1.93^{*}$ & .794 & .046 & .03 & 3.83 \\
\hline Blended & 75-25 Blended & $4.57^{*}$ & .794 & .000 & 2.67 & 6.47 \\
\hline $75-25$ & 25-75 Blended & $-2.64^{*}$ & .794 & .004 & -4.54 & -.74 \\
\hline Blended & 50-50 Blended & $-4.57^{*}$ & .794 & .000 & -6.47 & -2.67 \\
\hline
\end{tabular}

Table 8. Competence comparisons among learning style groups

\begin{tabular}{|c|c|c|c|c|c|c|}
\hline \multirow[b]{2}{*}{ (I) $L S$} & \multirow[b]{2}{*}{ (J) $L S$} & \multirow{2}{*}{$\begin{array}{c}\text { Mean } \\
\text { Difference } \\
\quad(I-J)\end{array}$} & \multirow[b]{2}{*}{ Std. Error } & \multirow[b]{2}{*}{ Sig. } & \multicolumn{2}{|c|}{$\begin{array}{l}\text { 95\% Confidence } \\
\text { Interval }\end{array}$} \\
\hline & & & & & $\begin{array}{l}\text { Lower } \\
\text { Bound }\end{array}$ & $\begin{array}{l}\text { Upper } \\
\text { Bound }\end{array}$ \\
\hline \multirow[t]{3}{*}{ Diverger } & Assimilator & -1.57 & .916 & .324 & -3.98 & .84 \\
\hline & Converger & $4.29^{*}$ & .916 & .000 & 1.88 & 6.70 \\
\hline & Accomodator & $2.57^{*}$ & .916 & .032 & .16 & 4.98 \\
\hline \multirow[t]{3}{*}{ Assimilator } & Diverger & 1.57 & .916 & .324 & -.84 & 3.98 \\
\hline & Converger & $5.86^{*}$ & .916 & .000 & 3.45 & 8.27 \\
\hline & Accomodator & $4.14^{*}$ & .916 & .000 & 1.73 & 6.55 \\
\hline \multirow[t]{3}{*}{ Converger } & Diverger & $-4.29^{*}$ & .916 & .000 & -6.70 & -1.88 \\
\hline & Assimilator & $-5.86^{*}$ & .916 & .000 & -8.27 & -3.45 \\
\hline & Accomodator & -1.71 & .916 & .250 & -4.12 & .70 \\
\hline \multirow[t]{3}{*}{ Accomodator } & Diverger & $-2.57^{*}$ & .916 & .032 & -4.98 & -.16 \\
\hline & Assimilator & $-4.14^{*}$ & .916 & .000 & -6.55 & -1.73 \\
\hline & Converger & 1.71 & .916 & .250 & -.70 & 4.12 \\
\hline
\end{tabular}

Based on observed means. The error term is Mean Square(Error)=8,512. An asterisk (*) signifies that the mean difference is significant at the .05 level.

Competency scores of teacher candidate students in each group of blended-learning forms and learning-style-type combinations are visible in Figure 1. It appears as though people with the diverger learning-style type are better in BL1 learning (25-75 blended) than assimilators, converters, and accommodators (each of them in order) are in BL2 learning (50-50 blended), BL3 (75-25 blended), and BL3 (75-25 blended). 


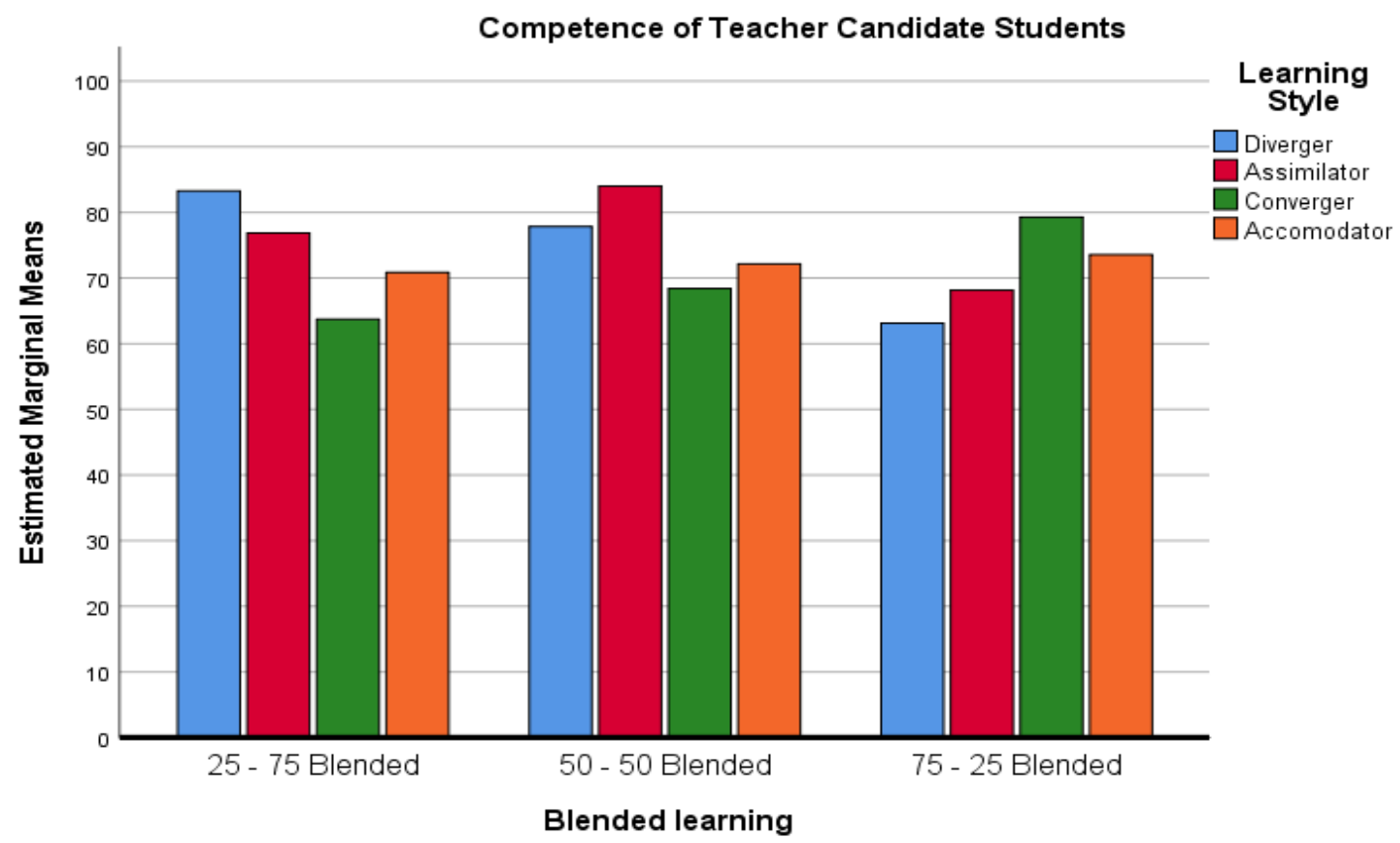

Figure 1. Teacher candidates' competence based on learning style in blended learning

\section{Discussion}

The forms of diversity of online and face-to-face learning in combination (blended learning) turned out to have a different impact on the competencies of prospective teacher students in real terms; and the data was in line with the findings of Kim McShane (2004). It means that the composition of online and face-to-face learning is essential to consider when implementing blended learning. It supports the work of López-Pérez, Pérez-López, \& Rodríguez-Ariza (2011), which states that using blended learning is not only based on simple integration of classroom teaching with digital media but that it also needs to pay attention to the other side, including forms of incorporation that are more appropriate. That makes blended learning superior in practice because it can create learning patterns and learning materials that are diverse in a flexible manner when helping students in their learning, as stated by George-Walker \& Keeffe (2010).

Competencies based on the type of learning style turned out that some of them did not show significant differences, especially those who were close together-namely, the type group diverged against the assimilator type group and the converger-type group towards the accommodator-type group. It has further strengthened the findings of Huang (2018) that not all learning styles provide significant differences in academic achievement. That is possible because the learning process takes place in the adjacent. Namely, it takes places between the process of concrete experience and reflective observation (diverger type) adjacent to the process of reflective observation and active experimentation (assimilator type). The same thing takes place between the process of active experimentation and abstract conceptualization (converger type). This is adjacent to the process of abstract conceptualization and reflective observation (accommodator type). The competencies of the diverger-type group with the converger-type group and the competencies of the assimilator and accommodator groups were significantly different. However, this is in line with supporting research-Toyama \& Yamazaki (2019) and Martinez \& Tuesca (2019)—which state that different learning styles provide significantly different learning outcomes.

Based on the learning group, the learning style type of diverger group (with a composition of 25 percents online and 75 percents of face-to-face learning) showed higher competence in learning, while the converger type group (with a composition of 75 percents online and 25 percents face-to-face learning) was higher in learning. That gives the meaning of students with the type of diverger learning style that is better in learning that is more directed towards traditional learners, while the converger type group is non-traditional as stated by Svinicki \& Dixon (1987), Vince (1998), and Wynd \& Bozman (1996). While the group-type assimilators are better at learning with a composition of 50 percents online and 50 percents face-to-face learning, and the accommodator type is learning with a composition 
of 75 percents online and 25 percents face-to-face learning. It shows that different individuals in different conditions tend to produce different results in line with Yang, \& Quadir (2018), Shen \& Palmeri (2016), She (2005), and Premlatha, Dharani, \& Geetha (2014).

\section{Conclusion}

The findings mean that students with different types of learning styles, when taught through blended learning, need to consider the composition of online learning and face-to-face learning in order to get maximum results. Through different combinations, they are giving different influences on the professional competence of teacher candidate students. Likewise, the varied types of learning styles are not significantly different (even though some show lesser differences). However, in order to teach teacher candidate students of electrical engineering through blended learning, it is necessary to identify their learning styles types first as a basis for choosing the appropriate approach, so that they can obtain maximum learning outcomes.

\section{Implications}

Learning styles have been found to play an essential role in the process of forming teacher competency. Therefore, forming learning groups based on the learning styles of students should be considered, so that the results obtained can be maximized. Learning styles from students are explored first, for that purpose.

\section{Limitations}

This study only focuses on three types of compositions of online learning and face-to-face learning groups in the context of blended learning. These compositions were imposed on prospective teacher students (in the field of electrical engineering) with various types of learning styles. Based on that, there is an opportunity for subsequent researchers to review other factors that play a role in the teaching and learning process through blended learning - with other forms of fusion being seen from various other learning characteristics including cognitive style and cognitive control.

\section{Acknowledgment}

The Authors would like to thank Directorate of Research and Community Service Strengthening, Ministry of Research, Technology and Higher Education of the Republic of Indonesia (Grant No.190/SP2H/LT/DRPM/2019).

\section{References}

Afacan, Y. (2015). Exploring the effectiveness of blended learning in interior design education. Innovations in Education and Teaching International, 53(5), 508-518. https://doi.org/10.1080/14703297.2015.1015595

Ahonen, E., Pyhältö, K., Pietarinen, J. \& Soini, T. (2014). Teachers' professional beliefs about their roles and the pupils' roles in the school. Teacher Development, 18(2), 177-197. https://doi.org/10.1080/13664530.2014.900818

Alexakis, G. \& Andert, D. (2015). Learning at the speed of readiness: An express learning model. Journal of Hospitality \& Tourism Education, 27(4), 147-160. https://doi.org/10.1080/10963758.2015.1089512

Ansari Ricci, L., Persiani, K., Williams, A. D. \& Ribas, Y. (2019). Preservice general educators using co-teaching models in math and science classrooms of an urban teacher residency programme: Learning[-]inclusive practices in teacher training. International Journal of Inclusive Education, 23(5), 1-14. https://doi.org/10.1080/13603116.2018.1563643

Baran, E., Correia, A.-P. \& Thompson, A. (2011). Transforming online teaching practice: Critical analysis of the literature on the roles and competencies of online teachers. Distance Education, 32(3), 421-439. https://doi.org/10.1080/01587919.2011.610293

Bicen, H., Ozdamli, F. \& Uzunboylu, H. (2012). Online and blended learning approach on instructional multimedia development courses in teacher education. Interactive Learning Environments, 22(4), 529-548. https://doi.org/10.1080/10494820.2012.682586

Boelens, R., De Wever, B. \& Voet, M. (2017). Four key challenges to the design of blended learning: A systematic literature review. Educational Research Review. https://doi.org/10.1016/j.edurev.2017.06.001

Bolsen, T., Evans, M. \& Fleming, A. M. (2016). A comparison of online and face-to-face approaches to teaching introduction to American government. Journal of Political Science Education, 12(3), 302-317. https://doi.org/10.1080/15512169.2015.1090905

Botts, R. T., Carter, L. \& Crockett, C. (2018). Using the blended learning approach in a quantitative literacy course. 
PRIMUS, 28(3), 236-265. https://doi.org/10.1080/10511970.2017.1371264

Bower, M., Kenney, J., Dalgarno, B., Lee, M. J. W. \& Kennedy, G. E. (2014). Patterns and principles for blended synchronous learning: Engaging remote and face-to-face learners in rich-media real-time collaborative activities. Australasian Journal of Educational Technology, 30(3), 261-272. https://doi.org/10.14742/ajet.v30i3.1697

Broadbent, J. (2017). Comparing online and blended learner's self-regulated learning strategies and academic performance. Internet and Higher Education, 33(2), 24-32. https://doi.org/10.1016/j.iheduc.2017.01.004

Brunton, B. (2014). Learning styles and student performance in introductory economics. Journal of Education for Business, 90(2), 89-95. https://doi.org/10.1080/08832323.2014.980716

Çardak, Ç. S. \& Selvi, K. (2016). Increasing teacher candidates' ways of interaction and levels of learning through action research in a blended course. Computers in Human Behavior, 61(2), 488-506]. https://doi.org/10.1016/j.chb.2016.03.055

Chandra, V. \& Briskey, J. (2012). ICT driven pedagogies and its impact on learning outcomes in high school mathematics. International Journal of Pedagogies and Learning, 7(1), 73-83. https://doi.org/10.5172/ijpl.2012.7.1.73

Chang-Tik, C. (2017). Impact of learning styles on the community of inquiry presences in multi-disciplinary blended learning environments. Interactive Learning Environments, 26(6), 827-838. https://doi.org/10.1080/10494820.2017.1419495

Chapman, M. \& Hassein, U. (2018). Improving student engagement in a flipped classroom. EDULEARN18 Proceedings, 10773. https://doi.org/10.21125/edulearn.2018.2637

Chimmalgi, M. (2018). Off-line virtual microscopy in teaching histology to the undergraduate medical students: Do the benefits correlate with the learning style preferences? Journal of the Anatomical Society of India, 67(2), 186-192. https://doi.org/10.1016/j.jasi.2018.11.010

Chmiel, A. S., Shaha, M. \& Schneider, D. K. (2017). Introduction of blended learning in a master program: Developing an integrative mixed method evaluation framework. Nurse Education Today, 48(1), 172-179. https://doi.org/ org/10.1016/j.nedt.2016.10.008

Courtney, M. H. \& Kelly, A. K. (2015). A preliminary comparison of online and face-to-face process groups. Journal of Technology in Human Services, 33(3), 241-262. https://doi.org/10.1080/15228835.2015.1038376

Cuesta Medina, L. (2017). Blended learning: Deficits and prospects in higher education. Australasian Journal of Educational Technology, 34(1), 42-56. https://doi.org/10.14742/ajet.3100

Cutri, R. M. \& Whiting, E. F. (2018). Opening spaces for teacher educator knowledge in a faculty development program on blended learning course development. Studying Teacher Education, 14(2), 125-140. https://doi.org/10.1080/17425964.2018.1447920

De Jong, T., Linn, M. C. \& Zacharia, Z. C. (2013). Physical and virtual laboratories in science and engineering education. Science, 340(6130), 305-308. https://doi.org/10.1126/science.1230579

DeCoito, I. (2006). Innovations in science education: Challenging and changing teachers' roles and beliefs. Canadian Journal of Science, Mathematics and Technology Education, 6(4), 339-350. https://doi.org/10.1080/14926150609556709

Dendir, S. (2018). Performance differences between face-to-face and online students in economics. Journal of Education for Business, 94(3), 175-184. https://doi.org/10.1080/08832323.2018.1503586

Donnelly, R. (2006). Blended problem-based learning for teacher education: lessons learnt. Learning, Media and Technology, 31(2), 93-116. https://doi.org/10.1080/17439880600756621

Dunn, R., Giannitti, M. C., Murray, J. B., Rossi, I., Geisert, G. \& Quinn, P. (1990). Grouping students for instruction: Effects of learning style on achievement and attitudes. The Journal of Social Psychology, 130(4), 485-494. https://doi.org/10.1080/00224545.1990.9924610

George-Walker, L. D. \& Keeffe, M. (2010). Self-determined blended learning: A case study of blended learning design. Higher Education Research \& Development, 29(1), 1-13. https://doi.org/10.1080/07294360903277380

Gilboy, M. B., Heinerichs, S. \& Pazzaglia, G. (2015). Enhancing student engagement using the flipped classroom. Journal of Nutrition Education and Behavior, 47(1), 109-114. https://doi.org/10.1016/j.jneb.2014.08.008

Goodwin, A. L. \& Kosnik, C. (2013). Quality teacher educators=quality teachers? Conceptualizing essential domains 
of knowledge for those who teach teachers. Teacher Development, 17(3), 334-346. https://doi.org/10.1080/13664530.2013.813766

Green, A. J. \& Sammons, G. E. (2014). Student learning styles: Assessing active learning in the hospitality learners model. Journal of Hospitality \& Tourism Education, 26(1), 29-38. https://doi.org/10.1080/10963758.2014.880617

Haruehansawasin, S. \& Kiattikomol, P. (2017). Scaffolding in problem-based learning for low-achieving learners. The Journal of Educational Research, 111(3), 363-370. https://doi.org/10.1080/00220671.2017.1287045

Hortovanyi, L. \& Ferincz, A. (2015). The impact of ICT on learning on-the-job. The Learning Organization, 22(1), 2-13. https://doi.org/10.1108/tlo-06-2014-0032

Huang, T.-C. (2018). Do different learning styles make a difference when it comes to creativity? An empirical study. Computers in Human Behavior, 87(10). https://doi.org/10.1016/j.chb.2018.10.003

Hughes, G. (2007). Using blended learning to increase learner support and improve retention. Teaching in Higher Education, 12(3), 349-363. https://doi.org/10.1080/13562510701278690

Hunt, A.-M. (2015). Blended online learning in initial teacher education: A professional inquiry into pre-service teachers' inquiry projects. Journal of Open, Flexible and Distance Learning, 19(2), 48-60.

Inoue, Y. (2010). Cases on online and blended learning technologies in higher education. Chocolate Avenue, USA: Information Science Reference.

Kantonidou, M. M. \& Chatzarakis, G. E. (2005). Technical teacher training in Greece: Trends, concerns and innovative attempts. European Journal of Teacher Education, 28(3), 245-258. https://doi.org/10.1080/02619760500268766

Keltikangas, K. \& Martinsuo, M. (2009). Professional socialization of electrical engineers in university education. European Journal of Engineering Education, 34(1), 87-95. https://doi.org/10.1080/03043790902721470

Kennedy, M. M. (2016). How does professional development improve teaching? Review of Educational Research, 86(4), 945-980. https://doi.org/10.3102/0034654315626800

Khusainova, A. \& Lukoyanova, M. (2018). Professional standards of the teacher and pedagogical ICT tools in [the] structure of the "ICT in education and cultural activities" discipline in the process of training bachelors of teacher education. INTED2018 Proceedings. https://doi.org/10.21125/inted.2018.0849

Kimmelmann, N. \& Lang, J. (2018). Linkage within teacher education: Cooperative learning of teachers and student teachers. European Journal of Teacher Education, 42(1), 52-64. https://doi.org/10.1080/02619768.2018.1547376

Kirschner, P. A. (2017). Stop propagating the learning styles myth. Computers \& Education, 106, 166-171. https://doi.org/10.1016/j.compedu.2016.12.006

Kissau, S. (2014). Type of instructional delivery and second language teacher candidate performance: Online versus face-to-face. Computer Assisted Language Learning, 28(6), 513-531. https://doi.org/10.1080/09588221.2014.881389

Kolb, D. A. (1984). Experiential learning. Englewood Cliffs, NJ: Prentice-Hall.

Kömür, Ş. (2010). Teaching knowledge and teacher competencies: A case study of Turkish preservice English teachers. Teaching Education, 21(3), 279-296. https://doi.org/10.1080/10476210.2010.498579

Kuo, Y.-C., Belland, B. R., Schroder, K. E. E. \& Walker, A. E. (2014). K-12 teachers' perceptions of and their satisfaction with interaction type in blended learning environments. Distance Education, 35(3), 360-381. https://doi.org/10.1080/01587919.2015.955265

Kurtz, T., Mogle, J., Sliwinski, M. J. \& Hofer, S. M. (2013). Individual differences in task-specific paired associates learning in older adults: The role of processing speed and working memory. Experimental Aging Research, 39(5), 493-514. https://doi.org/10.1080/0361073x.2013.839024

Lim, C. P., Yan, H. \& Xiong, X. (2015). Development of pre-service teachers' information and communication technology (ICT) in education competencies in a mainland Chinese university. Educational Media International, 52(1), 15-32. https://doi.org/10.1080/09523987.2015.1005425

López-Pérez, M. V., Pérez-López, M. C. \& Rodríguez-Ariza, L. (2011). Blended learning in higher education: Students' perceptions and their relation to outcomes. Computers \& Education, 56(3), 818-826. 
https://doi.org/10.1016/j.compedu.2010.10.023

Manolis, C., Burns, D. J., Assudani, R. \& Chinta, R. (2013). Assessing experiential learning styles: A methodological reconstruction and validation of the Kolb Learning Style Inventory. Learning and Individual Differences, 23, 44-52. https://doi.org/10.1016/j.lindif.2012.10.009

Martinez, E. G. \& Tuesca, R. (2019). Learning styles and gross anatomy assessment outcomes at a Colombian school of medicine. Educación Médica, 20(2), 79-83. https://doi.org/10.1016/j.edumed.2017.12.012

McIlveen, P., Perera, H. N., Baguley, M., van Rensburg, H., Ganguly, R., Jasman, A. \& Veskova, J. (2018). Impact of teachers' career adaptability and family on professional learning. Asia-Pacific Journal of Teacher Education, 47(2), 103-117. https://doi.org/10.1080/1359866x.2018.1444141

McShane, K. (2004). Integrating face-to-face and online teaching: Academics' role concept and teaching choices. Teaching in Higher Education, 9(1), 3-16. https://doi.org/10.1080/1356251032000155795

Mirabella, V., Kimani, S., Gabrielli, S. \& Catarci, T. (2004). Accessible e-learning material: A no-frills avenue for didactical experts. New Review of Hypermedia and Multimedia, 10(2), 165-180. https://doi.org/10.1080/13614560412331325253

Mohamed, Z., Valcke, M. \& De Wever, B. (2016). Are they ready to teach? Student teachers' readiness for the job with reference to teacher competence frameworks. Journal of Education for Teaching, 43(2), 151-170. https://doi.org/10.1080/02607476.2016.1257509

Morgan, J. D. (2015). Online versus face-to-face accounting education: A comparison of CPA exam outcomes across matched institutions. Journal of Education for Business, 90(8), 420-426. https://doi.org/10.1080/08832323.2015.1087371

Moss, C. M. \& Brookhart, S. M. (2009). Advancing formative assessment in every classroom: A guide for instructional leaders. Alexandria, USA: Association for Supervision and Curriculum Development

Ndlovu, M. C. \& Mostert, I. (2017). Teacher perceptions of Moodle and Throughput in a blended learning programme for in-service secondary school mathematics teachers. Africa Education Review, 15(2), 131-151. https://doi.org/10.1080/18146627.2016.1241667

Nemetz, P. L., Eager, W. M. \& Limpaphayom, W. (2017). Comparative effectiveness and student choice for online and face-to-face classwork. Journal of Education for Business, 92(5), 210-219. https://doi.org/10.1080/08832323.2017.1331990

Nickels, M. \& Gartner, A. (2018). Rethinking the mathematics block: A blended STEM approach. Kappa Delta Pi Record, 54(4), 186-189. https://doi.org/10.1080/00228958.2018.1515548

Parsons, A. W., Ankrum, J. W. \& Morewood, A. (2016). Professional development to promote teacher adaptability. Theory Into Practice, 55(3), 250-258. https://doi.org/10.1080/00405841.2016.1173995

Pekkarinen, V. \& Hirsto, L. (2017). University lecturers' experiences of and reflections on the development of their pedagogical competency. Scandinavian Journal of Educational Research, 61(6), 735-753. https://doi.org/10.1080/00313831.2016.1188148

Phillips, C. J., Stott, D. H. \& Birrell, H. V. (1987). The effects of learning style on progress towards literacy and numeracy. Educational Review, 39(1), 31-40. https://doi.org/10.1080/0013191870390103

Premlatha, K. R., Dharani, B. \& Geetha, T. V. (2014). Dynamic learner profiling and automatic learner classification for an adaptive e-learning environment. Interactive Learning Environments, 24(6), 1054-1075. https://doi.org/10.1080/10494820.2014.948459

Ruhalahti, S., Aarnio, H. \& Ruokamo, H. (2018). Deep learning evaluation in vocational teacher education: Conducted on the principles of authentic and dialogical collaborative knowledge construction. Nordic Journal of Vocational Education and Training, 8(2), 22-47. https://doi.org/10.3384/njvet.2242-458x.188222

Ruhalahti, S., Korhonen, A.-M. \& Rasi, P. (2017). Authentic, dialogical knowledge construction: A blended and mobile teacher education program. Educational Research, 59(4), 373-390. https://doi.org/10.1080/00131881.2017.1369858

Satar, H. M. \& Akcan, S. (2014). Pre-service language teachers' reflections on the implementation of a blended-learning environment. Turkish Online Journal of Qualitative Inquiry, 5(3). https://doi.org/10.17569/tojqi.43134

She, H.-C. (2005). Promoting students' learning of air pressure concepts: The interrelationship of teaching 
approaches and student learning characteristics. The Journal of Experimental Education, 74(1), 29-52. https://doi.org/10.3200/JEXE.74.1.29-52

Shen, J. \& Palmeri, T. J. (2016). Modeling individual difference in visual categorization. Visual Cognition, 24(3), 260-283. https://doi.org/10.1080/13506285.2016.1236053

Stoltzfus, M. W. (2016). Active learning in the flipped classroom: Lessons learned and best practices to increase student engagement. The Flipped Classroom, Volume 1: Background and Challenges, 105-122. https://doi.org/10.1021/bk-2016-1223.ch008

Svinicki, M. D. \& Dixon, N. M. (1987). The Kolb model modified for classroom activities. College Teaching, 35(4), 141-146. https://doi.org/10.1080/87567555.1987.9925469

Toyama, M. \& Yamazaki, Y. (2019). Are there effects of a match between learning style and teaching style in an EFL classroom? Innovation in Language Learning and Teaching, 13(3), 1-16. https://doi.org/10.1080/17501229.2019.1575386

Vince, R. (1998). Behind and beyond Kolb's learning cycle. Journal of Management Education, 22(5), 304-319. https://doi.org/10.1177\%2F105256299802200304

Vitale, J. M. \& Linn, M. C. (2018). Designing virtual laboratories to foster knowledge integration: Buoyancy and density. Cyber-Physical Laboratories in Engineering and Science Education, 163-189. https://doi.org/10.1007/978-3-319-76935-6_7

Vizeshfar, F. \& Torabizadeh, C. (2018). The effect of teaching based on the dominant learning style on nursing students' academic achievement. Nurse Education in Practice, 28, 103-108. doi.org/10.1016/j.nepr.2017.10.013

Wang, Y. \& Gao, X. (2016). Exploring the expectation differences in teachers' roles in English MA class presentation. Teacher Development, 20(1), 92-105. https://doi.org/10.1080/13664530.2015.1105862

Wetzel, A. P., De Arment, S. T. \& Reed, E. (2015). Building teacher candidates' adaptive expertise: Engaging experienced teachers in prompting reflection. Reflective Practice, 16(4), 546-558. https://doi.org/10.1080/14623943.2015.1064380

Wilke, D. J., King, E., Ashmore, M. \& Stanley, C. (2016). Can clinical skills be taught online? Comparing skill development between online and F2F students using a blinded review. Journal of Social Work Education, 52(4), 484-492. https://doi.org/10.1080/10437797.2016.1215276

William, F. G. (1999). Effects of learning-style-responsive versus traditional study strategies on achievement, study, and attitudes of suburban eighth-grade mathematics students. Research in Middle-Level Education Quarterly, 22(3), 19-41. https://doi.org/10.1080/10848959.1999.11670148

Wong, K. L., Lee, C. K. J., Chan, K. S. J. \& Kennedy, K. J. (2018). Teacher self-efficacy in cultivating students to become "good citizens": A Hong Kong case. Teacher Development, 23(2), 155-173. https://doi.org/10.1080/13664530.2018.1550435

Wynd, W. R. \& Bozman, C. S. (1996). Student Learning Style: A Segmentation Strategy for Higher Education. Journal of Education for Business, 71(4), 232-235. https://doi.org/10.1080/08832323.1996.10116790

Yang, J. C. \& Quadir, B. (2018). Individual differences in an English learning achievement system: gaming flow experience, gender differences, and learning motivation. Technology, Pedagogy, and Education, 27(3), 351-366. https://doi.org/10.1080/1475939x.2018.1460618

Zerihun, Z., Beishuizen, J. \& Van Os, W. (2011). Conceptions and practices in teaching and learning: implications for the evaluation of teaching quality. Quality in Higher Education, 17(2), 151-161. https://doi.org/10.1080/13538322.2011.582793

Zhu, C., Wang, D., Cai, Y. \& Engels, N. (2013). What core competencies are related to teachers' innovative teaching? Asia-Pacific Journal of Teacher Education, 41(1), 9-27. https://doi.org/ 10.1080/1359866x.2012.753984

Zwart, D. P., Van Luit, J. E. H., Noroozi, O. \& Goei, S. L. (2017). The effects of digital learning material on students' mathematics learning in vocational education. Cogent Education, 4(1). https://doi.org/10.1080/2331186x.2017.1313581 